\title{
Melanocortin 4 receptor (MC4R) gene variants in children and adolescents having familial early-onset obesity: genetic and clinical characteristics
}

\author{
Ayça Aykut ${ }^{1} \cdot$ Samim Özen ${ }^{2} \cdot$ Damla Gökşen ${ }^{2} \cdot$ Aysun Ata $^{2} \cdot$ Hüseyin Onay ${ }^{1} \cdot$ Tahir Atik $^{3} \cdot$ Şükran Darcan ${ }^{2}$. \\ Ferda Özkinay ${ }^{1,3}$
}

Received: 19 January 2020 / Revised: 24 February 2020 / Accepted: 2 March 2020 / Published online: 18 March 2020

(C) Springer-Verlag GmbH Germany, part of Springer Nature 2020

\begin{abstract}
Melanocortin 4 receptor gene plays an important role in food intake, energy balance, and weight control. The autosomal dominantly inherited $M C 4 R$ variants cause obesity by causing hyperphagia and decreased sense of satiety. Homozygous variants are rarely reported, and they cause earlier/severe obesity. Our objective is to determine the $M C 4 R$ gene variant frequency in children and adolescents with familial early-onset obesity. One hundred thirty-nine children and adolescents ( 57 girls $/ 82$ boys) whose weight increase started before the age of 5 years and who had early-onset obesity in at least one of their first-degree relatives were included in the study. Obesity is defined as body mass index (BMI) of $\geq 95$ th percentile, and as extreme obesity is defined if the BMI $\geq 120 \%$ of the 95 th percentile or $\geq 35 \mathrm{~kg} / \mathrm{m}^{2}$. Children having genetic syndromes associated with obesity and mental retardation or taking drugs that promote changes in eating behavior or weight were excluded from the study. Coding region of the $M C 4 R$ gene was sequenced by using the Illumina MiSeq Next Generation Sequencing System. The mean age of the patients was $7.3 \pm 3.7$ years, and the mean BMI SDS was $3.7 \pm 0.7$. While 118 patients $(85 \%)$ were prepubertal, 21 patients $(15 \%)$ were pubertal. Seven different variants were identified in 12 patients by giving a variant detection rate of $8.6 \%$, of these five were previously identified missense variants p.N274S, p.S136F, p.V166I, p.R165W, and p.I291SfsX10. One homozygous variant p.I291SfsX10 (c.870delG) was detected in a severely obese 2-year-old boy, and other variants were heterozygous. Two novel variants were found: p.M200del and p.S188L. By using the in silico analysis software, these novel variants were predicted to be disease causing.
\end{abstract}

Communicated by Peter de Winter

Samim Özen

samimozen@gmail.com

Ayça Aykut

ayca.aykut@ege.edu.tr

Damla Gökșen

damla.goksen68@gmail.com

Aysun Ata

draysunkaya@gmail.com

Hüseyin Onay

onayhuseyin@gmail.com

Tahir Atik

tahir.atik@ege.edu.tr
Şükran Darcan

sukran.darcan@gmail.com

Ferda Özkinay

f.ferda.ozkinay@ege.edu.tr

1 Department of Medical Genetics, Ege University School of Medicine, İzmir, Turkey

2 Department of Pediatric Endocrinology, Ege University School of Medicine, İzmir, Turkey

3 Department of Pediatric Genetics, Ege University School of Medicine, İzmir, Turkey 
Conclusion: MC4R gene variants are quite common in childhood obesity in Turkish population. Screening the variants in $M C 4 R$ gene is necessary in patients with severe childhood-onset obesity. In such patients, comorbidities of obesity can be seen from early years.

What is known

- The frequency of MC4R mutations in obese patients was approximately 0-6.3\%.

What is new

- In obese Turkish pediatric population, unlike other European countries, MC4R gene variants are quite common as we found a variant rate of $8.6 \%$

- We believe it is necessary to screen the variants in MC4R gene in patients with severe childhood-onset obesity and who had early-onset obesity in at least one of their first-degree relatives in Turkish population.

Keywords Monogenic obesity $\cdot$ Pediatrics $\cdot M C 4 R$

\begin{tabular}{|c|c|}
\hline \multicolumn{2}{|c|}{ Abbreviations } \\
\hline BMI & Body mass index \\
\hline HOMA-IR & $\begin{array}{l}\text { Homeostasis model assessment-insulin } \\
\text { resistance }\end{array}$ \\
\hline MC4R & Melanocortin 4 receptor \\
\hline SDS & Standard deviation score \\
\hline TSH & Thyroid-stimulating hormone \\
\hline
\end{tabular}

\section{Introduction}

Obesity is a worldwide epidemic with rates nearly doubling over the last 30 years [1]. Although the major driving cause behind obesity is overrating, there is a considerable evidence of a significant genetic contribution for regulation of body weight. In 1998, MC4R variants were reported to be associated with dominantly inherited human obesity [2].

$M C 4 R$ codes a protein called melanocortin 4 receptor, which is mainly found in the hypothalamus and is responsible for controlling appetite and satiety. It encodes the MC4R protein, a G protein-coupled receptor that binds the $\alpha$-melanocytestimulating hormone ( $\alpha$-MSH). In murine models, MC4 receptors have been found to be involved in the feeding behavior, regulation of metabolism, sexual behavior, and male erectile function [3]. In animal models, deletion of $M C 4 R$ also results in hyperphagia and increased body fat, ultimately leading to hepatic steatosis without atherogenic diet [4].

Since the first variants in $M C 4 R$ in obese humans were reported over 20 years ago, several groups have reported the sequence variants in $M C 4 R$ in different populations. Based on the studies and observations, $M C 4 R$ variants seem to have an incomplete penetrance and some degree of codominance. Individuals that carry pathogenic variants have a 4.5 -fold increased risk of developing obesity when compared with noncarriers [5].

There is a large variation in the frequency of variants between different studies ranging from 0.5 to $8.5 \%[2,6]$. More than 200 variants have been identified to date, primarily heterozygous dominant acting missense variants [7]. Heterozygous variants are also found in $2-5 \%$ of subjects with extreme pediatric obesity, making this the most common genetic form of obesity in pediatric age group [8, 9]. Homozygous $M C 4 R$ variants have also been identified in offsprings from consanguineous families $[9,10]$.

In this study, the screening of the $M C 4 R$ coding sequence of Turkish obese children and adolescents who have earlyonset obesity was described. The aims of the present study were (i) to determine the frequency of $M C 4 R$ variants in a cohort of Turkish clinically obese children and adolescents and (ii) to search for variants in the promoter region of $M C 4 R$. In addition, a list of all variants described in the literature, which will aid the interpretation of variants found in a diagnostic setting, was provided.

\section{Material and method}

One hundred thirty-nine children and adolescents (57 girls/82 boys) whose weight increase started before the age of 5 years, who presented to Pediatric Endocrinology and Medical Genetics Department of Ege University Medicine Faculty, and who had the history of early-onset obesity in at least one of their firstdegree relatives were included in the study. Obesity is defined as body mass index (BMI) of $\geq 95$ th percentile, and as extremely obese is defined if the BMI $\geq 120 \%$ of the 95 th percentile or $\geq$ $35 \mathrm{~kg} / \mathrm{m}^{2}$ [11]. Children having genetic syndromes associated with obesity and mental retardation or taking drugs that promote changes in eating behavior or weight were excluded from the study. Coding region of the $M C 4 R$ gene was sequenced by using the Illumina MiSeq Next Generation Sequencing System.

Physical examinations of the cases were performed by an experienced pediatric endocrinologist and were recorded in the patient data form. Height was measured as the nearest $0.5 \mathrm{~cm}$ by stadiometer. Body weight was measured using an electronic scale sensitive to the nearest $100 \mathrm{~g}$. BMI was calculated as $\mathrm{kg} /$ $\mathrm{m}^{2}$. Body weight, height, and BMI's SD scores were calculated using Turkish national anthropometric references [12]. Blood pressure values above 95 th percentile according to age, sex, and height were accepted as hypertensive [13]. Blood glucose, insulin, and serum lipid levels measured at admission during 
morning fasting were recorded from the file data. Homeostasis model assessment that shows the insulin resistance is calculated by the following formula: insulin resistance (HOMA-IR) value $=$ fasting blood glucose $(\mathrm{mg} / \mathrm{dl}) \times 0.055 \times$ fasting insulin $(\mathrm{mIU} /$ $\mathrm{ml} / 22.5$. In a systemic review including 8732 children and adolescents, the value of HOMA-IR associated with metabolic syndrome ranges from 2.30 to 3.54 [14]. The cutoff value of 3.16 was chosen in line with previous studies in obese children and adolescents [15-18]. Written informed consents were obtained from all the participants. This study was approved by the Ege University Ethics Committee.

\section{Genetic analysis}

Molecular diagnosis of DNA was isolated from a $200-\mu$ l blood sample using the QIAamp DNA Blood Mini QIAcube Kit and a QIAcube instrument (QIAGEN, Hilden, Germany) according to the manufacturer's specifications. The entire coding sequence of MC4R gene (NM_ *155541) was PCR amplified and sequenced on Illumina MiSeq System using 300-cycle Reagent Kit V2. Base-calling and sequence alignment were performed by using the built-in MISEQ 4 REPORTER software.

The primers used were $M C 4 R-\mathrm{F}$ (5'-ATCA ATTCAGGGGGACACTG $3^{\prime}$ ) and $M C 4 R$-R (5'-GGCC ATCAGGAACATGTGGA-3') for $M C 4 R$ gene sequencing.

All variants in $M C 4 R$ gene with a frequency of less than $0.5 \%$ in public databases (e.g., NCBI dbSNP build141 [19], 1000 Genomes Project [20], Exome Aggregation Consortium (ExAC) [21], NHLBI Exome Sequencing Project (ESP), and Exome Variant Server [22]) were selected. The prediction of the potential damaging effects of variants on protein activity with different algorithms was identified using several in silico prediction tools such as MutationTaster [23] and SIFT [24]. The variants were evaluated by VarSome [25], evolutionary conservation scores [24] determined, and variants categorized in accordance with the ACMG recommendations [26].

\section{Statistical analysis}

The statistical analysis of the data was carried out by using SPSS 21.0 (Chicago, IL, USA). Mann-Whitney $U$-test and chi-square test were used to compare numerical and categorical variables, respectively. A $p$ value of $<0.05$ was accepted to represent statistical significance. The data were presented as mean $\pm \mathrm{SD}$ or $n(\%)$.

\section{Results}

The average age of admission of 139 cases included in the study was $7.3 \pm 3.7$ years (between 1.3 and 15 years), mean height SDS was $1.4 \pm 1.1$, mean BMI was $39.2 \pm 8.9 \mathrm{~kg} / \mathrm{m}^{2}$, and mean BMI SDS was $3.6 \pm 0.7 \mathrm{SD}$. While $118(85 \%)$ cases were in the prepubertal period, $21(15 \%)$ cases were in the pubertal period. Age of obesity onset was found as $3.2 \pm 2.1$ years in the study group. Mean birth weight was $3546 \pm 746 \mathrm{~g}$.

Seven different variants in 12 patients were identified by giving a variant detection rate of $8.6 \%$. Of these, 5 were previously identified missense variants p.N274S, p.S136F, p.V166I, p.R165W, and p.I291SfsX10. Previously identified p.N274S variant was the most common detected variant and was found in 4 cases from different families. Two novel variants were found: p.M200del and p.S188L. By using the in silico analysis software, these novel variants were predicted to be disease causing (Table 1).

Age of obesity onset was found to be lower in the variant carrier cases ( $2.2 \pm 1.1$ vs $4.7 \pm 2.9$ years, $p=0.01)$. No statistically significant difference was found between the cases with and without variant in terms of age, height SDS, BMI, BMI SDS, blood pressure, serum fasting glucose, and lipid values. HOMA-IR value was higher in variant carrier group $(5.4 \pm 1.8$ vs $3.9 \pm 2.6, p=0.04$ ) (Table 2). No significant difference was found between the groups in terms of blood pressure and serum lipid levels.

In variant carrier group, mean BMI SDS was found as 3.8 \pm 1.5 SDS. While insulin resistance was found in $11(91.6 \%)$ cases, acanthosis nigricans was found in $3(25 \%)$ cases, liver steatosis in $5(41.6 \%)$ cases, psychiatric disorder in $2(16.6 \%)$ cases, and TSH elevation in $2(16.6 \%)$ cases. High blood pressure was observed in only one case. Diabetes was not detected in any patient.

Homozygous p.I291Sfs*10 variant causing the formation of stop codon resulting in frameshift was detected in a 2-yearold male patient (patient 5), and he had increased appetite and weight increase from the sixth month of his life. BMI SDS value of this case was $7.3 \mathrm{SD}$ (severe obesity). The patient's mother was shown to have a heterozygous variant (mother's BMI SDS, 1.5 SD), and no sample could be taken from the father. It was decided that the variant was pathological because variant caused the stop codon and had a correlation with the disease in in silico programs.

One patient (patient 12) admitted to us with severe obesity had p.N274S variant, and he had also hepatosteatosis, thyroidstimulating hormone (TSH) elevation $(5.19 \mathrm{mIU} / \mathrm{L})$, systolic and diastolic non-dipper hypertension, and insulin resistance. During follow-up due to rapid weight gain and major depressive disorder, sleeve gastrectomy operation was performed in 16 years old (175 kg + 5.64 SDS; $194 \mathrm{~cm}+3.15$ SDS; BMI, 46.5 + 3.76 SDS). Table 1 shows the clinical data, comorbidities, and genetic characteristics of the cases with $M C 4 R$ gene variants.

\section{Discussion}

Heterozygous $M C 4 R$ variants have been reported in obese people from various ethnic groups. The prevalence of 


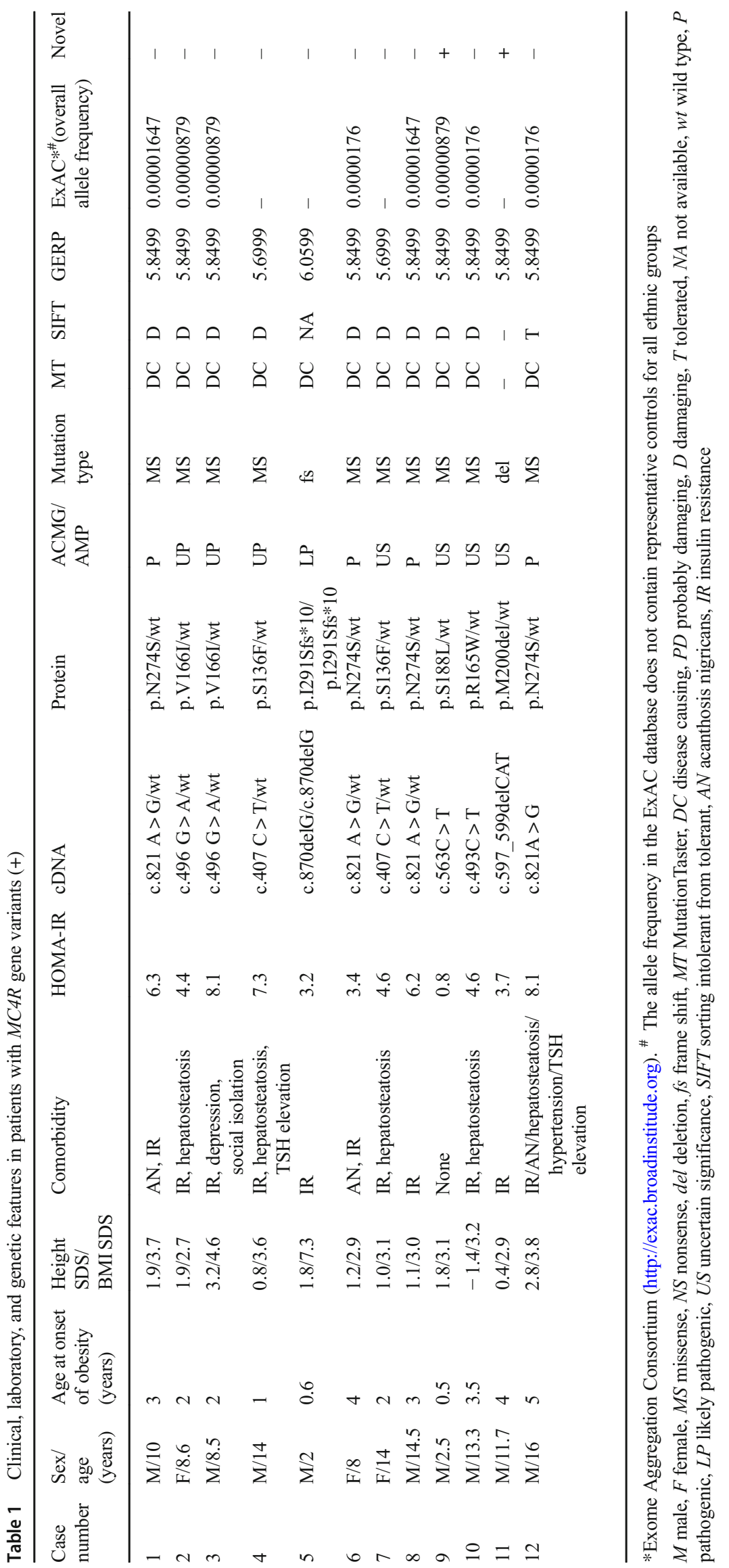


Table 2 Comparison of clinical and laboratory findings between $M C 4 R$ variants detected and undetected patients

\begin{tabular}{llll}
\hline & $\begin{array}{l}M C 4 R(-) n(127) \\
\text { Fean } \pm \text { SDS }\end{array}$ & $\begin{array}{l}M C 4 R(+) n(12) \\
\text { Mean } \pm \text { SDS }\end{array}$ & $p$ \\
\hline Age (years) & $8.1 \pm 2.3$ & $7.8 \pm 5.2$ & 0.17 \\
Age of onset of obesity & $4.7 \pm 2.9$ & $2.2 \pm 1.1$ & 0.01 \\
Height SDS & $1.4 \pm 0.9$ & $1.2 \pm 1.4$ & 0.22 \\
BMI (kg/m ${ }^{2}$ ) & $37.1 \pm 10.5$ & $42.2 \pm 9.9$ & 0.15 \\
BMI SDS & $3.6 \pm 0.8$ & $3.8 \pm 1.5$ & 0.16 \\
Systolic blood pressure (mmHg) & $97.3 \pm 32.0$ & $93.9 \pm 21.1$ & 0.45 \\
Diastolic blood pressure (mmHg) & $64.4 \pm 28.0$ & $62.7 \pm 26.3$ & 0.57 \\
Fasting glucose (mg/dL) & $85.6 \pm 10.7$ & $89.9 \pm 10.2$ & 0.54 \\
Fasting insulin (mIU/ml) & $17.8 \pm 11.9$ & $20.2 \pm 11.9$ & 0.21 \\
HOMA-IR & $3.9 \pm 2.6$ & $5.4 \pm 1.8$ & 0.04 \\
HbAlc $(\%)$ & $5.4 \pm 0.5$ & $5.5 \pm 0.7$ & 0.66 \\
Total cholesterol (mg/dL) & $189.3 \pm 78.1$ & $191.7 \pm 82.1$ & 0.76 \\
Triglycerides (mg/dL) & $153.2 \pm 66.2$ & $167.1 \pm 62.6$ & 0.88 \\
HDL (mg/dl) & $41.6 \pm 9.8$ & $40.2 \pm 10.2$ & 0.97 \\
\hline
\end{tabular}

$M C 4 R$ melanocortin 4 receptor, SDS standard deviation score, HOMA-IR homeostasis model assessment-insulin resistance, $B M I$ body mass index, $H D L$ high density lipoprotein pathogenic $M C 4 R$ variants varies between 0.5 and $8.5 \%$ of obese adult and pediatric patients [27]. Single-nucleotide polymorphisms in MC4 gene are also related to obesity and its metabolic complications [28]. Previously, Demiralp D et al. [29] studied MC4R gene polymorphisms in obese Turkish children. In their study, they showed that p.V103I polymorphism was $4.5 \%$ in complicated obese children and p.E42K polymorphism was $9 \%$ in familial obese children and $1.5 \%$ in complicated obese children. De Rosa et al. [30] study 312 African American and Latino children with severe nonsyndromic obesity, and their variant rate was $2.6 \%$. In the recent study by Tunç et al. [31], MC4R gene variant was investigated in 47 morbid obese children. This study composed of the cases that have the same ethnic origin, and the variant rate was given as $8.5 \%$ that is very similar to the present study [28]. Akınc1 et al. [32] study 105 patients with severe (BMI > 3) early-onset obesity for 41 previously known obesity-related genes by targeted next-generation sequencing analysis, and they found monogenic obesity of $10.4 \%$ in Turkish population. In our study, nucleotide sequence of the coding region of $M C 4 R$ was determined in 139 unrelated probands with familial early-onset obesity, and $8(8.6 \%)$ probands with variants that alter the amino acid sequence of the receptor were found.

Beckers S et al. [33] reported the frequency of polymorphism in a cohort including 123 obese children and adolescents as $3.25 \%$, and they did not detect pathogenic $M C 4 R$ variant in any case. However, in their study, the sample group consisted of only obese patients, and it did not discriminate any early-onset obesity. Farooqi et al. [10] examined the nucleotide sequence of the $M C 4 R$ gene in 500 individuals with severe childhood-onset obesity. Of them 29 individuals
(5.8\%) had pathogenic variants in MC4R: 23 were heterozygous and 6 were homozygous. The reason of these frequency differences in the literature may be due to different inclusion criteria of studies or different ethnic origins.

Homozygous or compound heterozygous $M C 4 R$ variants are associated with more severe obesity than the heterozygous form, revealing a codominant mode of inheritance [34]. Fewer than 20 cases of homozygous, $M C 4 R$ variants have been reported in the literature. In the present study, one patient's extreme obesity was secondary to homozygous p.I291Sfs* 10 variant in MC4R gene. In the study of Tunç et al. [28], BMI SDS of 6-year-old index case having heterozygous form of the same variant was given as 3.01. On the other hand, in the present study, the case having homozygous variant was 2 years old and severely obese with BMI SDS of 7.3 at an earlier age.

In patients with $M C 4 R$ variants, insulin resistance is expected from the early years of life due to hyperphagia and early-onset obesity. In the present study, it was found that 91.6\% of the cases with $M C 4 R$ variant had insulin resistance that was proven by the laboratory. HOMA-IR values were statistically higher in cases with variant compared with the cases without variants. Even though Tunç et al. [31] reported that there was no insulin resistance in their study group, fasting insulin values were median $22.4 \pm 7.5 \mathrm{mIU} / \mathrm{L}$, high for age references $(0-17 \mathrm{mIU} / \mathrm{L})$. Previous studies also reported the presence of insulin resistance in cases with $M C 4 R$ variants [10, 35]. In 1362 Indian children, MC4R rs12970134 polymorphism is also related to increased insulin resistance [36]. Within the variant carrier cases in the present study, insulin resistance was determined as early as 2 years. For this reason, cases with $M C 4 R$ variant should be monitored for insulin resistance and related complications from earlier age. 
There are a limited number of studies showing the correlation between $M C 4 R$ and hypothalamic-pituitary-thyroid axis. While serum free T4 levels were normal in all cases in the sample group, elevation of isolated TSH was observed in two cases, and TSH values were between 5.2 and $7.3 \mathrm{mIU} / \mathrm{L}$ in the follow-up of a case with normal autoantibody levels, thyroid ultrasonography, and urine iodine excretion. No decreased in free T4 or apparent hypothyroidism was observed. In the previous study by Farooqi $\mathrm{S}$ et al. [10], isolated TSH elevation was reported in 1 of 29 patients with $M C 4 R$ variant. In the study conducted by Huszar D et al. [37] on MC4R knockout mice, no correlation between the MC4R molecule and the thyroid axis was found. Vella KR et al. [38] showed in their study that mice with neuropeptide-Y and MC4R deficiency had impaired thyrotropin-releasing hormone, TSH, and thyroid hormone suppression in hypothalamo-hypophyseal areas and also neuropeptide- $\mathrm{Y}$ and MC4R were required for the hepatic metabolism of T4. Further studies are needed regarding the effect of the MC4R molecule on the hypothalamicpituitary-thyroid axis, which also has an effect on energy metabolism.

A significant correlation has been reported between obesity/overweight and some psychiatric disorders especially attention deficit hyperactivity disorder and depression. This suggested that these two conditions might share common molecular pathways despite their heterogeneity. However, the pathogenesis of these correlations is not known clearly [39, 40]. Agranat-Meged A et al. [40] suggested that attention deficit hyperactivity disorder was statistically significantly more frequent in the cases with $\mathrm{C} 271 \mathrm{R}$ variant in the $M C 4 R$ gene. In their study, Mergen et al. [41] showed a bipolar psychiatric disorder in a female patient who had p.N274S heterozygous variant. In the current series, a 8.5-year-old male patient had a history of 1-year follow-up for social isolation due to the diagnosis of depression by a child and adolescent psychiatrist. One patient with p.N274S variant and morbid obesity also had major depressive disorder, and he was hospitalized in an adolescent psychiatry clinic due to major depression. Whether these two conditions may be secondary to obesity, separate clinical entity, or secondary to variant in $M C 4 R$ gene, it was not yet fully explained [42-44]. Further studies are required in this field.

Moreover, plenty of pharmacological studies are ongoing in obesity treatment. Setmelanotide (MC4R agonist) treatment in $M C 4 R$ variant carriers was investigated in a randomized, double-blind, placebo-controlled Phase Ib study. After 28 days, a mean difference in weight loss of $0.6 \mathrm{~kg} /$ week was observed in $M C 4 R$ variant carriers compared with the placebo subtracted group [45]. As a result, detection of variant carrier patients may also be important for the chance of treatment in the near future.

In conclusion, $M C 4 R$ gene variants are quite common in childhood early-onset obesity in Turkish population. It is necessary to screen the variants in $M C 4 R$ gene in patients with severe childhood-onset obesity. Cases with $M C 4 R$ variants should be closely followed up for obesity complications and comorbidities from early ages.

Authors' contribution A.A: Methodology, conceptualization, investigation

S.O: Software, investigation, writing, original draft preparation

D.G: Investigation

A.A: Investigation, writing

H.O: Methodology, software

T.A: Formal analysis, investigation

S.D: Project administration

F.O: Writing, reviewing, editing

Funding information Ege University Faculty of Medicine

\section{Compliance with ethical statements}

Conflict of interest The authors declare that they have no conflict of interest.

Ethical approval This article does not contain any studies with human participants or animals performed by any of the authors.

Informed consent Informed consent was obtained from all individual participants included in the study.

\section{References}

1. Baxter J, Armijo PR, Flores L, Krause C, Samreen S, Tanner T (2019) Updates on monogenic obesity in a multifactorial disease. Obes Surg 29:4077-4083. https://doi.org/10.1007/s11695-01904200-Z

2. Vaisse C, Clement K, Guy-Grand B, Froguel P (1998) A frameshift mutation in human MC4R is associated with a dominant form of obesity. Nat Genet 20(2):113-114. https://doi.org/10.1038/2407

3. Dubern B, Clément K, Pelloux V, Froguel P, Girardet J-P, GuyGrand B, Tounian P (2001) Mutational analysis of melanocortin-4 receptor, agouti-related protein, and $\alpha$-melanocyte-stimulating hormone genes in severely obese children. J Pediatr 139(2):204-209. https://doi.org/10.1067/mpd.2001.116284

4. Hao H, Lin R, Li Z, Shi W, Huang T, Niu J, Han J, Li Q (2019) MC4R deficiency in pigs results in hyperphagia and ultimately hepatic steatosis without high-fat diet. Biochem Biophys Res Commun 520(3):651-656. https://doi.org/10.1016/j.bbrc.2019.08. 016

5. MacKenzie RG (2006) Obesity-associated mutations in the human melanocortin-4 receptor gene. Peptides 27(2):395-403. https://doi. org/10.1016/j.peptides.2005.03.064

6. Weiss RE, Refetoff S (2016) Genetic diagnosis of endocrine disorders, 2nd edn. Academic Press, Amsterdam, p 444

7. Kühnen P, Krude H, Biebermann H (2019) Melanocortin-4 receptor signalling: importance for weight regulation and obesity treatment. Trends Mol Med 25(2):136-148. https://doi.org/10.1016/j.molmed. 2018.12.002

8. Vaisse C, Clement K, Durand E, Hercberg S, Guy-Grand B, Froguel P (2000) Melanocortin-4 receptor mutations are a frequent and heterogeneous cause of morbid obesity. J Clin Invest 106(2): 253-262. https://doi.org/10.1172/JCI9238 
9. Farooqi IS, Yeo GSH, Keogh JM, Aminian S, Jebb SA, Butler G, Cheetham T, O'Rahilly S (2000) Dominant and recessive inheritance of morbid obesity associated with melanocortin 4 receptor deficiency. J Clin Invest 106(2):271-279. https://doi.org/10.1172/ JCI9397

10. Farooqi IS, Keogh JM, Yeo GSH, Lank EJ, Cheetham T, O'Rahilly S (2003) Clinical spectrum of obesity and mutations in the melanocortin 4 receptor gene. N Engl J Med 348(12):1085-1095. https://doi.org/10.1056/NEJMoa022050

11. Styne DM, Arslanian SA, Connor EL, Farooqi IS, Murad MH, Silverstein JH, Yanovski JA (2017) Pediatric obesity-assessment, treatment, and prevention: an Endocrine Society Clinical Practice guideline. J Clin Endocrinol Metab 102:709-757. https://doi.org/ $10.1210 /$ jc. $2016-2573$

12. Neyzi O, Bundak R, Gökçay G, Günöz H, Furman A, Darendeliler F, Bas F (2015) Reference values for weight, height, head circumference, and body mass index in Turkish children. J Clin Res Pediatr Endocrinol 7(4):280-293. https://doi.org/10.4274/jcrpe. 2183

13. Flynn JT, Kaelber DC, Baker-Smith CM et al (2017) Clinical practice guideline for screening and management of high blood pressure in children and adolescents. Pediatrics 140(3):e20171904. https:// doi.org/10.1542/peds.2018-1739

14. Arellano-Ruiz P, Garcia-Hermoso A, Cavero-Redondo I, PozueloCarrascosa D, Martinez-Vizcaino V, Solera-Martinez M (2019) Homeostasis model assessment cut-off points related to metabolic syndrome in children and adolescents: a systematic review and meta-analysis. Eur J Pediatr Dec 178(12):1813-1822 http://link. springer.com/10.1007/s00431-019-03464-y

15. Shashaj B, Luciano R, Contoli B, Morino GS, Spreghini MR, Rustico C, Sforza RW, Dallapiccola B, Manco M (2016) Reference ranges of HOMA-IR in normal-weight and obese young Caucasians. Acta Diabetol 53(2):251-260. https://doi.org/10.1007/ s00592-015-0782-4

16. Lee JM, Okumura MJ, Davis MM, Herman WH, Gurney JG (2006) Prevalence and determinants of insulin resistance among U.S. adolescents: a population-based study. Diabetes Care 29(11):24272432. https://doi.org/10.2337/dc06-0709

17. Bervoets L, Massa G (2016) Classification and clinical characterization of metabolically "healthy" obese children and adolescents. J Pediatr Endocrinol Metab 29(5):553-560. https://doi.org/10.1515/ jpem-2015-0395

18. Kurtoglu S, Akin L, Kendirci M, Hatipoglu N, Elmali F, Mazicioglu M (2012) The absence of insulin resistance in metabolic syndrome definition leads to underdiagnosing of metabolic risk in obese patients. Eur J Pediatr 171(9):1331-1337. https://doi.org/ 10.1007/s00431-012-1724-6

19. Sherry ST, Ward MH, Kholodov M, Baker J, Phan L, Smigielski EM, Sirotkin K (2001) dbSNP: the NCBI database of genetic variation. Nucleic Acids Res 29(1):308-311. https://doi.org/10.1093/ $\operatorname{nar} / 29.1 .308$

20. The 1000 Genomes Project Consortium (2015) A global reference for human genetic variation. Nature 526(7571):68-74. https://doi. org/10.1038/nature 15393

21. Karczewski KJ, Weisburd B, Thomas B, Solomonson M, Ruderfer DM, Kavanagh D et al (2017) The ExAC browser: displaying reference data information from over 60000 exomes. Nucleic Acids Res 45(D1):D 840-D 845. https://doi.org/10.1093/nar/gkw971

22. NHLBI Exome Variant Server. http://evs.gs.washington.edu/EVS/

23. Schwarz JM, Rödelsperger C, Schuelke M, Seelow D (2010) MutationTaster evaluates disease-causing potential of sequence alterations. Nat Methods 7(8):575-576. https://doi.org/10.1038/ nmeth0810-575

24. Pollard KS, Hubisz MJ, Rosenbloom KR, Siepel A (2010) Detection of nonneutral substitution rates on mammalian phylogenies. Genome Res 20(1):110-121. https://doi.org/10. 1101/gr.097857.109

25. Kopanos C, Tsiolkas V, Kouris A, Chapple CE, Albarca Aguilera M, Meyer R, Massouras A (2019) VarSome: the human genomic variant search engine. Wren J, editor. Bioinformatics 35(11):19781980. https://doi.org/10.1093/bioinformatics/bty897

26. ACMG Laboratory Quality Assurance Committee, Richards S, Aziz N, Bale S, Bick D, Das S et al (2015) Standards and guidelines for the interpretation of sequence variants: a joint consensus recommendation of the American College of Medical Genetics and Genomics and the Association for Molecular Pathology. Genet Med 17(5):405-423. https://doi.org/10.1038/gim.2015.30

27. Cooiman MI, Kleinendorst L, Aarts EO, Janssen IMC, van Amstel HKP, Blakemore AI et al (2019) Genetic obesity and bariatric surgery outcome in 1014 patients with morbid obesity. Obes Surg 30: 470-477. https://doi.org/10.1007/s11695-019-04184-w

28. Gao L, Wang L, Yang H, Pan H, Gong F, Zhu H (2019) MC4R single nucleotide polymorphisms were associated with metabolically healthy and unhealthy obesity in Chinese northern Han populations. Int J Endocrinol 2019:1-9. https://doi.org/10.1155/2019/ 4328909

29. Demiralp DO, Berberoğlu M, Akar N (2011) Melanocortin-4 receptor polymorphisms in Turkish pediatric obese patients. Clin Appl Thromb 17(1):70-74. https://doi.org/10.1177/ 1076029609354330

30. De Rosa MC, Chesi A, McCormack S, Zhou J, Weaver B, McDonald $\mathrm{M}$ et al (2019) Characterization of rare variants in MC4R in African American and Latino children with severe early-onset obesity. J Clin Endocrinol Metab 104(7):2961-2970. https://doi.org/10.1210/jc.2018-02657

31. Tunç S, Demir K, Tükün FA, Topal C, Hazan F, Sağlam B, Nalbantoğlu Ö, Yıldız M, Özkan B (2017) Melanocortin-4 receptor gene mutations in a group of Turkish obese children and adolescents. J Clin Res Pediatr Endocrinol 9(3):216-221. https://doi.org/ $10.4274 /$ jcrpe. 4225

32. Akıncı A, Türkkahraman D, Tekedereli İ, Özer L, Evren B, Sahin İ, Kalkan T, Çürek Y, Çamtosun E, Döğer E, Bideci A, Güven A, Eren E, Sangün Ö, Çayır A, Bilir P, Törel Ergür A, Ercan O (2019) Novel mutations in obesity-related genes in Turkish children with non-syndromic early onset severe obesity: a multicentre study. J Clin Res Pediatr Endocrinol 11(4):341-349. https://doi.org/10. 4274/jcrpe.galenos.2019.2019.0021

33. Beckers S, Mertens I, Peeters A, Van Gaal L, Van Hul W (2006) Screening for melanocortin-4 receptor mutations in a cohort of Belgian morbidly obese adults and children. Int J Obes 30(2): 221-225. https://doi.org/10.1038/sj.ijo.0803126

34. Drabkin M, Birk OS, Birk R (2018) Heterozygous versus homozygous phenotype caused by the same MC4R mutation: novel mutation affecting a large consanguineous kindred. BMC Med Genet 19(1):135. https://doi.org/10.1186/s12881-018-0654-1

35. Fairbrother U, Kidd E, Malagamuwa T, Walley A (2018) Genetics of severe obesity. Curr Diab Rep 18(10):85. https://doi.org/10. 1007/s11892-018-1053-x

36. Prakash Dwivedi O, Tabassum R, Chauhan G, Kaur I, Ghosh S, Marwaha RK, Tandon N, Bharadwaj D (2013) Strong influence of variants near MC4R on adiposity in children and adults: a crosssectional study in Indian population. J Hum Genet 58(1):27-32. https://doi.org/10.1038/jhg.2012.129

37. Huszar D, Lynch CA, Fairchild-Huntress V, Dunmore JH, Fang Q, Berkemeier LR, Gu W, Kesterson RA, Boston BA, Cone RD, Smith FJ, Campfield LA, Burn P, Lee F (1997) Targeted disruption of the melanocortin-4 receptor results in obesity in mice. Cell 88(1): 131-141. https://doi.org/10.1016/S0092-8674(00)81865-6

38. Vella KR, Ramadoss P, Lam FS, Harris JC, Ye FD, Same PD, O'Neill NF, Maratos-Flier E, Hollenberg AN (2011) NPY and MC4R signaling regulate thyroid hormone levels during fasting 
through both central and peripheral pathways. Cell Metab 14(6): 780-790. https://doi.org/10.1016/j.cmet.2011.10.009

39. Porfirio MC, Giovinazzo S, Cortese S, Giana G, Lo-Castro A, Mouren MC, Curatolo P, Purper-Ouakil D (2015) Role of ADHD symptoms as a contributing factor to obesity in patients with MC4R mutations. Med Hypotheses 84(1):4-7. https://doi.org/10.1016/j. mehy.2014.11.004

40. Agranat-Meged A, Ghanadri Y, Eisenberg I, Ben Neriah Z, Kieselstein-Gross E, Mitrani-Rosenbaum S (2008) Attention deficit hyperactivity disorder in obese melanocortin-4-receptor (MC4R) deficient subjects: a newly described expression of MC4R deficiency. Am J Med Genet B Neuropsychiatr Genet 147B(8):1547-1553. https://doi.org/10.1002/ajmg.b.30842

41. Mergen M, Mergen H, Ozata M, Oner R, Oner C (2001) RAPID COMMUNICATION: a novel melanocortin 4 receptor (MC4R) gene mutation associated with morbid obesity. J Clin Endocrinol Metab 86(7):3448-3448. https://doi.org/10.1210/jcem.86.7.7809

42. Mulugeta A, Zhou A, Vimaleswaran KS, Dickson C, Hyppönen E (2019) Depression increases the genetic susceptibility to high body mass index: evidence from UK Biobank. Depress Anxiety 36(12): 1154-1162. https://doi.org/10.1002/da.22963
43. Tyrrell J, Mulugeta A, Wood AR, Zhou A, Beaumont RN, Tuke MA, Jones SE, Ruth KS, Yaghootkar H, Sharp S, Thompson WD, Ji Y, Harrison J, Freathy RM, Murray A, Weedon MN, Lewis C, Frayling TM, Hyppönen E (2019) Using genetics to understand the causal influence of higher BMI on depression. Int J Epidemiol 48(3):834-848. https://doi.org/10.1093/ije/dyy223

44. Chaki S, Okuyama S (2005) Involvement of melanocortin-4 receptor in anxiety and depression. Peptides 26(10):1952-1964. https:// doi.org/10.1016/j.peptides.2004.11.029

45. Collet TH, Dubern B, Mokrosinski J, Connors H, Keogh JM, Mendes de Oliveira E, Henning E, Poitou-Bernert C, Oppert JM, Tounian P, Marchelli F, Alili R, le Beyec J, Pépin D, Lacorte JM, Gottesdiener A, Bounds R, Sharma S, Folster C, Henderson B, O'Rahilly S, Stoner E, Gottesdiener K, Panaro BL, Cone RD, Clément K, Farooqi IS, van der Ploeg L (2017) Evaluation of a melanocortin-4 receptor (MC4R) agonist (Setmelanotide) in MC4R deficiency. Mol Metab 6(10):1321-1329. https://doi.org/ 10.1016/j.molmet.2017.06.015

Publisher's note Springer Nature remains neutral with regard to jurisdictional claims in published maps and institutional affiliations. 